\title{
ANALYSIS OF THE IMPLEMENTATION OF THE POLICY PP 36/2017, PMK-165 2017 POST FORGIVENESS TAX (POST- TAX AMNESTY )
}

\author{
Suparmin \\ University of Pamulang \\ dosen01601@unpam.ac.id
}

\begin{abstract}
Taxes are the most important factors for the state finances to guarantee the continuity of national development without depending on natural resources and foreign aid. To encourage the compliance required taxs and expand the tax data base on 2016 published Act No. 11 The year 2016 about forgiveness tax (Tax Amnesty). Tax forgiveness Program given by the Government to the required taxs include the elimination of the tax should be are indebted, the elimination of tax administration and the elimination of the criminal sanction in the field of taxation of wealth obtained in 2015 and before that has not been reported in SPT.Although there are polemics at the beginning was launched. But there are benefits that are expected when PP-36/2017 policy implemented which will give the opportunity for Taxpayers who have followed the Tax Forgiveness Program but there are still the property which has not been or is not exposed in whole or for Taxpayers who qualify but it does not follow the tax forgiveness program so that the order of Article 18 of Act No. 11 The year 2016 about Tax Amnesty.In addition to the advantages there is also the downside to Taxpayers who follow the Tax Forgiveness program with Taxpayers who do not follow the tax forgiveness program. Taxpayers who have followed the Tax Forgiveness program, but by Fiskus has found wealth is not revealed it is considered as income when found the property that will be subject to Income Tax in accordance with the provisions of the legislation are speeding PPh plus the sanction of 200\%.For Taxpayers who did not join the Program tax forgiveness when found wealth is considered as income when found incur Income Tax plus the sanction in accordance with the provisions of legislation on taxes.
\end{abstract}

Keywords: Pasca Tax Amnesty, The Implementation and polemic of PP-36/2017's Policy

\section{INTRODUCTION}

After the success of the tax forgiveness program (Tax Amnesty) Directorate General of the Directorate General of Taxation) return to invite the community to report on his property which has not been/less reported through the Asset Disclosure program Voluntarily with the Final Tariff (PasFinal) (Roslani, 2017).

Prastowo (2017) stated that the rising of this rule is a follow up from the tax Amnesty program to provide legal certainty of post-Tax Amnesty. He holds that the rising of the PP-36/2017, PMK$165 / 2017$ is too long since the end of the period of the forgiveness of taxes (Tax Amnesty) so lapsed losing momentum. To provide sufficient information to the community, Prastowo asked TAXATION do socialization with the instruments and tools that can be easily understood by the required taxes. Second, in the implementation of taxation need to provide a signal to the 
public that TAXATION perform that action is measured. In addition polemics that occurred at this time due to a lack of information that circulates in the community. Should TAXATION do hearing public before the legalization of a rule. Input from the community is accommodated and which can be accommodated so that more rational (Prastowo, 2017).

Based on the above background and the author will analyze the implementation of the post-Tax Amnesty behind the response and polemics shrinking the business people about PP No. 36/2017 and PMK165/PMK.03/ 2017.

\section{LITERATURE REVIEW}

\subsection{Tax Amnesty}

Amnesty policy taxes done in the form of the secretion of the rights of the state to collect the tax should are indebted. Therefore, it is only fair if taxpayers are required to pay the Ransom Money on forgiveness of tax acquired when you want to obtain forgiveness. In the context of the implementation of the Act of Forgiveness Tax.

With the adherence to the principles or legal certainty, justice worthwhile, and the national interests, the purpose of amnesty tax among others:

1. Accelerate the growth and restructuring of the economy through the redirection of the wealth that among others will affect the improvement of domestic liquidity and increase the value of the exchange rate of the rupiah, refused, and increased investment;

2. Encourage the taxation reform toward a more equitable taxation system and the expansion of the data base of taxation is more valid, comprehensive, and integrated;
3. Increase tax revenues, which will be used for financing the development. Tax awareness material for higher education (2016).

\subsection{Subject of PP 36/2017}

The subject of the Government Regulation No. 36/2017 is:

1. Every Taxpayers who have an obligation to convey annual SPT $\mathrm{PPh}$ good Taxpayers The Private or Taxpayers Body, Taxpayers MSMES and the personal or body which has not yet become taxpayers, who have followed the tax forgiveness program but there are still treasure that have not yet been or less revealed in the statement and that have not yet been/does not follow the Tax Forgiveness program.

2. Indonesian citizens good which has Tax Forgiveness Program (Tax Amnesty) or not or not follow the Tax Forgiveness Program (Tax Amnesty) to who have followed the tax forgiveness Program but there are still treasure that have not yet been or less expressed in the letter of the statement. And for that has not been or is not participating in the program of Forgiveness Tax taxpayers qualify and does not convey the statement until the Tax Forgiveness period ended.

\section{METHODS}

To analyze the implementation of the policy PP-36/2017 Post Forgiveness Tax (post-Tax Amnesty) used qualitative method with descriptive eksplorative approach. Eksplorative approach (Kotler \& Keler, 2006) is a research method that aims to collect the initial information that will help the efforts of the assignment problem and formulate a hypothetical. While the 
descriptive approach is a research method that aims to expose (describing) something. So this approach aims to explore about the discourse on the implementation of the policy PP36/2017 in issuing Post Forgiveness Tax (post-Tax Amnesty) (Sumar cruse, 2016).

To clarify the picture regarding the opportunity, challenges, obstacles and the weakness of the implementation of the policy PP-36/2017 Post Forgiveness Tax (post-Tax Amnesty) used SWOT analysis (Strengths, Weaknesses, Opportunities and HMM). From this analysis can be determined the strategy and policy measures that can be taken (Suwarsono, 2000).

\section{RESULT AND DISCUSSION}

\subsection{Tax Forgiveness policy (Tax Amnesty) \\ 1. Policy Implementation of PP- 36/2017, PMK-165/2017}

Some time ago the Bank Indonesia do Payment gateway, namely all traffic international payments is the gateway and this can be accessed by taxation because transparency, accountability must indeed we continue to put forth, but this was indeed a cost that must be paid for example today people have already started to save money, save the consumption for fear/reluctant known yet wherever we consume wherever we invest there must have gladly, the heritage of the tax amnesty laws still continue to the front of the there are 4 things/no 4 issue :

1. Its the problem of wealth even though the process of Tax Amnesty finished but still apply the article 18 of Law Tax Amnesty a priority we have an impact on the tax system to the future.

2. Article 13 namely regarding repatriation, issues are the basis of repatriation on our supervision for 3 years into the future is the consequences.

3. Holding period of the problem of investment in Indonesia for 3 years this became the basis of our supervision to the future.

4. The correction information letter if there is still one paper/one count interconnected obligation starting 2016.

Four this is the impact of the Act of Forgiveness Tax (Tax Amnesty) calculated continue to the fore and will be interconnected with the tax obligations we start 2016. The prominent issues are Article 18, related to tax us into the future. Article 18 would like it does not like binding all required taxes good join Tax Forgiveness Program (Tax Amnesty) or not or not Tax Forgiveness Program (Tax Amnesty), this cannot be disputed again is closed with the Regulation of the Minister of Finance and win, then why not join Tax Amnesty not arranged in Article 18 indeed is the rule the aim is to encourage all participating Tax Amnesty with honest, all their wealth, observe, if all participating Tax Amnesty and all their wealth, observe then finished our taxation problems in the past e.g. to the back of the can we close even bookkeeping the allusion we can dispose.

This is called the revolution of taxation. Then what the splendid article 18 create us, one article set both participating Tax Amnesty and that it does not follow the Tax Amnesty. A remarkable Article 18 is one Article that turn off all taxation the past due to get Amnesty Tax, but turn over their wealth. Article 18 paragraph 1 of Act Tax Amnesty, tax the past forgiven, investigations of income closed, Vat closed, VAT BM closed, examination and etc. closed but Wealth turned on even Wealth become the object of new tax. Thus the article 18 of Act Tax 
Amnesty is the object of new tax for taxpayers for the government. The property which is owned by the Taxpayers before December 2015 which has not been reported in SPT 2015.

Article 18 just talk about the object has not been talking how to wear the taxation, then Act Amnesty Tax cannot stand alone the imposition of taxation with the Income Tax Laws. The Government Regulation 36/2017 is legal basis of the implementation of the Act on Income Tax. The tax imposed on the property which the object was regulated Act Amnesty Tax. It is an issue that we need to understand now PP 36/2017 was the imposition of taxation Official Assessing regulated when taxes are indebted is when the letter Examination Command (SP2) published so that when the Directorate General of Taxation to find the property which has not been reported in the Information Letter Amnesty Tax (SKET) or not yet entered into the SPT eat is the object of tax imposition of taxation set PP 36/2017 namely quotes, how to count them, The Basis of tax imposed (DPP) associated with Article 18, that PP 36/2017 set about tax on wealth.

Principle is if the Directorate General of Taxation find Wealth per December 2015 even though the object is sold, important owned per December 2015. For participating Amnesty Tax no timeout whenever found the imposition of the gladly done when found although found several times with sanctions $200 \%$. Understanding find not seen where the source. Each find information data and has not been reported or not yet entered into the SKET (Letter) Amnesty Tax as the object of tax. Wealth has not been reported to the PPh Final but with the regulation 165/2017 scheme is new path given to Taxpayers with SPT scheme of PPh Final not SKPKB scheme..
For those who join Amnesty taxs have two schemes to meet tax obligations PPh final borders:

1. Reported SPT PPh final according to the regulation of the Director General of 23/2017-165 or Per then finished, please also if confess many times. Before found by the Directorate General of Taxation.

2. Expectantly found by the Directorate General of Taxation will be in SP2/SKPKB with sanctions $200 \%$.

For those who did not join Amnesty taxs have 3 schemes with PMK- 165/2017:

1. Taxpayers can correct annual SPT $\mathrm{PPh}$ but must be subject to the Law of Income Tax and ACT ON COUP means can still be checked according to the years of obtaining wealth.

2. Waiting for Taxation find their wealth but the only until June 2019, after June 2019 could not in SKPKB sanctions $4 \%$ because the infection takes approximately 2 months penalty is calculated since SP2 sunrise/SKP sunrise.

3. Or with the regulation of the165/2017 report e.g. the PPh Final paid gladly, the earnings are no longer are indebted $\mathrm{PPh}$ Article 17. Or the Directorate General of Taxation find Wealth until June 2019. If selecting SPT time PPh final more simple because not filed Javanase all Wealth paid Income Tax and his wealth was considered new earnings at SPT presented so that when the report annual SPT 2017. Procedures for the way in accordance with the per the Directorate General of Taxation No. 23/2017 there is the type of new tax Income Tax final over Wealth PP 165/2017, essentially Amnesty Laws taxes. Quotes Act Income Tax.

SKET (Letter) is a replacement for the entire taxation. Because SKET in the preceding book A1, A2, A3, A4 (treasure in SPT, wealth in the land has 
not been reported, Wealth abroad in repatriation, Wealth stored in overseas). For Per through their wealth in SKET and wealth of the property which has not been reported from which the source of the attachment SKET no details are treasures that has not been reported as per December 2015.

Taxpayers who feel joined amnesty tax but still treated PP 36/2017 and PMK 165/PMK.03/2017 means there is still the property which has not been presented so one own why not reported entirely? just 2 percent and the value of the board of directors of his favor again is his name check and balance this is enforcement post-Tax Amnesty. How to evaluate the same with PP-36/2017 for cash money? For Wealth remains and to share value. The rich man who did not join the Tax Amnesty will be investigated until June 2019.

The period of the implementation of Amnesty Tax has ended, no longer Amnesty Tax "post-TAX AMNESTY "what happens after the Amnesty Tax?. PP 362017 about the imposition of Income Tax on certain Income a wealth of clean treated or regarded as production of "As" Implementation of the consequences for WP participating TA but there are treasures that are still not yet revealed or redirected out of the Unitary State of the republic at the time of holding the period, and for Taxpayers who did not join the TA but there is wealth that has not been reported in the annual SPT PPh. The Consequences of Article 18 of Act Amnesty Tax. The type of the consequences for participants Amnesty Tax:

1. Taxpayers not so repatriation/not invest Wealth repatriation for 3 years;

2. Divert wealth to the outside of the Unitary State of the Republic of Indonesia before 3 years.

The period of the implementation of Amnesty Tax has ended, no longer Amnesty Tax but what happens after the
Amnesty Tax (post-Tax Amnesty). The Directorate General of Taxation to invite the community Taxpayers to return reported substance which has not been reported through the Asset Disclosure program on a voluntary basis with the Final Tariff (FIT-Final). This Program in order to avoid the tax forgiveness program participants or Tax Amnesty from a fine income tax 200 percent or 2 percent month-on-month for nonparticipants Amnesty Tax. This program provides an opportunity for all Taxpayers who have wealth that still has not been reported in the annual SPT 2015 or disclosure Letter Property (SPH) to express their own assets to pay Income Tax with certain tariff (Saksama, 2016).

\subsection{The implementation of the PP $36 / 2017$ implementing rules in the Regulation of the- 165/PMK.03/2017}

In this program, the tariff for Taxpayers The Personal (OP) General of 30 per cent Taxpayers public bodies by 25 percent. As well as the WP, OP or the body with specific business income or work free less than or equal to $\mathrm{Rp} 4.8$ billion and/or employees with income less than or equal to $\mathrm{Rp} 632$ million a 12.5 percent.

\section{For Participants Tax Amnesty \\ example a):}

Moltres big entrepreneurs with omset always above Rp 10 billion, has followed the program Penganpunan taxs. In fact, he forgot is his savings in reconstructing his that have not been expressed in SPH. The value of the savings of $\mathrm{Rp} 500$ million. Moltres concerned will be subject to the sanction of Article 18 of Act Tax Amnesty to lift its sanctions of 200 percent.

What can Moltres do?

If MAKE SPT TIME PPH FINAL 
Income $=\operatorname{Rp} 500,000,000$ (wealth that has not been revealed is calculated as income)

Then PPh Final $=$ Rp500.000.000 $\mathrm{x}$ $30 \%=150,000.000,-($ multiplied by the tariff PP 36/2017 for personal people of $30 \%)$.

\section{IF FOUND BY THE TAX} INSPECTION:

Income $=\operatorname{Rp~500,000,000~(wealth~}$ that has not been revealed is calculated as income)

PPh Final $=$ Rp 500,000,000 x 30\% = Rp 150,000.000,-

Plus sanctions $=\mathrm{Rp} 150.000 .000 \mathrm{x}$ $200 \%=$ Rp. 300.000.000,- (Plus sanctions Article 18 of Act Tax Amnesty of 200\%).

2) For non- participants Tax Amnesty

Example b) :

Lugia entrepreneurs who did not join the program Tax Amnesty. She has found a house (worth $\mathrm{Rp} 2$ billion) results from one of the business which has not been revealed and paid gladly.

\section{If MAKE SPT TIME PPH FINAL} :

Income $=\mathrm{Rp}$ 2.000.000.000 (wealth that has not been reported is calculated as income)

Then $\mathrm{PPh}$ Final $=2.000 .000 .000 \mathrm{x}$ $30 \%=\mathrm{Rp} 600.000 .000$ (multiplied by the tariff PP 36/2017 for personal people of $30 \%$ ).

\section{If FOUND BY THE AUDIT :}

Income $=\mathrm{Rp} 2.000 .000 .000$ (wealth that has not been reported is calculated as income).

$\mathrm{PPh}$ Final $=\mathrm{Rp} 2.000 .000 .000 \times 30 \%$ $=$ Rp. 600.000.000,- (multiplied by the tariff PP 36/2017 for personal people of $30 \%$ )

plus sanctions $=R p 6.00 .000 .000 \times 2$ percent $=R p$ 12,000.000,- (Plus sanctions Article 18 of Law Tax Amnesty :2 percent per month maximum of 24 month).
This time of taxation has also given the opportunity according to Act No. 9 2017 to access financial institutions that owned by financial institutions such as banking and capital market. Then start 2018, financial institutions will routinely provide financial data to the Directorate General of Taxation, including financial data from 100 other countries that have agreed to exchange financial information in order to combat the fugitive tax across the country.

Therefore the Directorate General of Taxation urged all Taxpayers better yet and the first which has special Amnesty Tax and still have hidden assets to immediately take advantage of the procedures FIT-Final as regulated in the Regulation of this-165/2017. Before the Directorate General of Taxation find hidden assets data (Pratomo, 2017).

\subsection{SWOT analysis of the implementation of the Policy PP 36/2017 post-Tax Amnesty}

When used SWOT analysis, especially seen from the side of the strength of weakness, opportunities and challenges in the implementation of the policy implementation PP 36/2017 posttax Amnesty can be described as follows:

1. Strength (power)

a. The resources owned by the institution apparatus of the Directorate General of Taxation is currently insufficient to support the imposition of various policies especially post-policy tax Amnesty PP 362017.

b. When tax policies such as PP 36/2017 called post-policy Tax Amnesty applied then will create the willingness of society to follow/obey and fulfill tax obligations despite initially various fear criticize the policy.

c. This Policy is not a policy of Lifting guardianship taxs (Tax Amnesty) Volume II, but this 
policy is a follow up of the implementation of the Article 18 of Act Tax Amnesty.

d. It has confirmed PP 36/2017 post-Tax Amnesty and the rules of implementation of the Regulation of the165/PMK.03/2017.

\section{Weakness}

a. The policy of the Government Regulation No. 36/2017 post published Tax Forgiveness, distance time too long with the end of the time of the applicable Tax Amnesty, so taxpayer quite losing momentum.

b. Taxpayers along with the issuance of PP 36/2017 make confused taxpayers especially for those who have already joined the Program Amnesty Tax and invited to improve SPT.

c. The level of compliance required taxes which still low so will need explanation/Strategy socialization that assault to understand government policy regarding the implementation of the PP 36/2017 Post Forgiveness Tax.

d. Evaluation tax objects namely Wealth besides cash assessment by taxation but is professional and use skilled assessment.

e. Perception Taxpayers still many who stated that this policy is not balanced for Taxpayers who follow the Tax Forgiveness program with Taxpayers who do not follow the tax forgiveness program.

\section{Opportunities}

a. The purpose of this policy program is like the main purpose of Tax Forgiveness policy (Tax Amnesty) namely improve compliance required taxes.

b. The Main Objectives of the Policy Tax Forgiveness Tax Amnesty is to improve the compliance of Taxpayers. c. The success of the implementation of Tax Forgiveness as proof of the level of trust benefiting high enough is one of the opportunity to realize the purpose of the end in order to secure tax revenues and improve compliance required taxes.

d. The condition of the Indonesian economy growth provides the opportunity for the success of the PP 36/2017.

e. After the existence of the policy Tax Forgiveness and tax base up expected income from the tax base also increase.

f. Taxation invites the community Taxpayers to return reported substance which has not been reported through the Asset Disclosure program on a voluntary basis with the Final Tariff (FITFinal).

g. This Program provides an opportunity for all Taxpayers who have wealth that still has not been reported in the annual SPT 2015 and SPH to express their own assets to pay Income Tax with certain tariff (Saksama, 2016).

\section{Threats}

a. The challenges faced in this policy is not the weight of the challenges faced when the government issued a policy of Act of forgiveness tax.

b. Perception/community trust required taxes and entrepreneurs to the Directorate General of Taxation has not yet been fully, although the Directorate General of Taxation has been doing various efforts to build the trust of the community Taxpayers as implementing the reform of the bureaucracy service provision and open service of complaints about the issue of taxation, Kring 1500200 tax and others.

c. Many problems related to the forgiveness of tax so that the laws became increasingly complex 
therefore one of its policies is PP$36 / 2017$ to disseminate this policy will need to create the appropriate steps so that a taxpayers understand and is expected to be required to meet the tax liability taxations.

d. Indonesia is currently still have other issues related to the tax ratio of tax revenue to GDP.

\subsection{Polemics behind the policy of the Government Regulation no.36/2017 about the imposition of Income above a certain Income a wealth of clean treated or regarded as Income}

Roslani (2017) to evaluate the rules of post-Amnesty Tax PP-36/2017, PMK- 165/PMK.03/2017 on the second amendment of the Regulation of the 118/PMK.03/2016, this will cause the interpretation that the weight and will harm the required taxes. That article mentions, assessment of wealth in cash of cash equivalents will use nominal value, but for other than cash and equivalent, Property assessment will be done by the Director General of Taxation official assessment using the appropriate reference for the condition of the property in the last years or 2015 . Whereas, when Tax Forgiveness Program (Tax Amnesty) Taxpayers to self - assessment in calculating the value of their wealth. This will cause the interpretation that the weight and will harm the required taxes. Meanwhile the appeal of correction SPT to Taxpayers along with the issuance of PP 36/2017 make confused taxpayers especially for those who have already joined the Program Amnesty Tax and invited to improve SPT.

Saptono (2017) said PP 36/2017 ideally not rules that stand alone. The implementation of the PP 36/2017 is implementation of Legislation Tax Forgiveness and Act on Income Tax. In order not to have confused so this rule should be seen as a whole, for example understand the rules PP 36/2017 must be associated with the Article 13 and 18 Act Tax Forgiveness and Article 4 of the Act on Income Tax. Moreover the mechanism how to assess the wealth has been arranged also in accordance with circular Letter No. SE24/ACTING/2017 and SE24/ACTING/2016. Taxpayers do not need to be reactive and worries about excessive as the rising of the regulation is a follow up from the tax Amnesty Program to provide legal certainty after.

According to Prastowo (2017) the rising of the regulation is too long from the age of the period Tax Forgiveness so lapsed losing momentum. In addition to losing momentum rule is also quite the responsibility because it does not regulate the needed, such as the problem of the dispute and the issue of correction that often occurs in the community. To provide sufficient information to the community, TAXATION must take socialization with the instruments and tools that is easily understood by the required taxes, both in the implementation of taxation need to provide a signal to the public that they do that action regularly. PP-36/2017, PMK-165/ PMK.03/2017.

\section{CONCLUSIONS}

From the discussion of the above there are a few things that can be deduced among others:

1. The Government Regulation Number 362017 was the rule published by the government in order to pursue article 18 the laws No. 11 The year 2016 about Forgiveness Tax (Tax Amnesty) and the rules of implementation through the regulation of-165/ PMK.03/2017. So there is no reason to love does not like is the mandate of the law. 
2. PP-36/2017 can be successfully implemented if all parties to have the trust and understand the rules of implementation.

3. Although there are polemics at the beginning was launched. But there are benefits that are expected when PP-36/2017 policy implemented which will give the opportunity for Taxpayers who have followed the Tax Forgiveness Program but there are still the property which has not been or is not exposed in whole or for Taxpayers who qualify but it does not follow the tax forgiveness program so that the order of Article 18 of Act No. 11 The year 2016 about Tax Amnesty.

4. Can improve compliance additional Taxpayers and increase tax revenues.

5. This regulation is not applicable to the people who have income under the Tax-free Income (PTKP) or have their wealth from inheritance and/or grant which has been reported in SPT heirs and/or warner grants.

6. In addition to the advantages there is also the downside is for Taxpayers who follow the Tax Forgiveness program does not follow the tax forgiveness program. Taxpayers who have followed the Tax Forgiveness program, but by Fiscal has found wealth is not revealed it is considered as income when found incur Income Tax in accordance with the provisions of the legislation are speeding $\mathrm{PPh}$ plus the sanction of $200 \%$. For Taxpayers who did not join the Program tax forgiveness when found wealth is considered as income when found incur Income Tax plus the sanction in accordance with the provisions of legislation on taxs.

\section{REFERENCES}

Due, John F. (1985). Keuangan Negara, Jakarta : UI Press.

Dye, Thomas R. (2008). Understanding Public Policy. New Jersey : Pearson Prentice Hall.

Kotler, Philip dan Keller L. Kevin. (2006). Metodologi Penelitian: Aplikasi Dalam Pemasaran. Jakarta: Indes.

Mansury, R. (1999). Kebijakan Fiskal. Jakarta : Penerbit YP4.

Mansury, R. (2000). Kebijakan Perpajakan, Jakarta: Yayasan Pengembangan dan Penyebaran Pengetahuan Perpajakan.

Nugroho, Rian. (2011). Public Policy, Jakarta: PT. Elex Media Komputindo.
Rahayu, Ani. S. (2010). Pengantar Kebijakan Fiskal. Jakarta: Bumi Aksara.

Rosdiana, Haula dan Irianto, Edi S. (2012). Pengantar Ilmu Pajak : Kebijakan dan Implementasi di Indonesia. Jakarta: PT. Rajagrafindo Persada.

Roslani. (2017). Patriot Insight Pajak 2017. Bina Pajak Edisi VI "Manfaatkan Pas-Final Sekarang Juga".

Saksama, H. Yoga. (2017). Sambutan Direktur Penyuluhan, Pelayanan, dan Hubungan Masyarakat DITJEN PAJAK. 
Santoso, Budihardjo R. (1998). Pengantar Hukum Pajak. Bandung: Refika Aditama.

Saptono, B. Prianto. (2017). Perpajakan. Jakarta: PT Pratama Indomitra.

Subarsono, A.G. (2006). Analisis Kebijakan Publik: Konsep, Teori dan Aplikasi. Yogyakarta: Pustaka Pelajar.

Tim Edukasi Perpajakan Ditjen Pajak. (2016). Materi Terbuka Kesadaran Pajak Untuk Perguruan Tinggi. Jakarta: Direktorat Jenderal Pajak
Kementerian Keuangan Republik Indonesia.

Wanarno, Budi. (2014). Kebijakan Publik: Teori dan Proses. Jakarta: PT. Buku Kita.

Widodo, Joko. (2007). Analisis Kebijakan Publik: Konsep dan Aplikasi Analisis Proses Kebijakan Publik. Malang: Bayumedia Publishing.

Winarno, Budi. (2009). Public Policy: Analisis, Strategi, Advokasi, Teori dan Praktek. Surabaya: CV Putra Media 